\title{
Chemical composition and fat profile of meat from crossbred goats reared under feedlot systems
}

\author{
Marta Suely Madruga ${ }^{1}$, Ertha Janine Lacerda de Medeiros ${ }^{2}$, Wandrick Hauss de Sousa ${ }^{3}$, \\ Maria das Graças Gomes Cunha ${ }^{3}$, José Morais Pereira Filho ${ }^{4}$, Rita de Cássia Ramos do \\ Egypto Queiroga ${ }^{5}$
}

${ }^{1}$ Departamento de Tecnologia Química e de Alimentos, Universidade Federal da Paraíba (DTQA/UFPB), Campus I, João Pessoa, PB, CEP: $59.059-900$

2 Programa de Pós-graduação em Ciência e Tecnologia de Alimentos (PPGCTA/DTQA/UFPB).

${ }^{3}$ Empresa Estadual de Pesquisa Agropecuária da Paraíba - EMEPA. Rua Eurípides Tavares, $n^{\circ}$ 210, Tambiá, João Pessoa, PB, CEP: $58.013-290$

${ }^{4}$ Departamento de Medicina Veterinária, Universidade Federal de Campina Grande (DMV/UFCG), Caixa Postal 64, Jatobá, Patos, PB, CEP: $58.700-970$

${ }^{5}$ Departamento de Nutrição, Universidade Federal da Paraíba (DN/UFPB), Campus I, João Pessoa, PB, CEP: 59.059-900.

\begin{abstract}
This study aimed to evaluate the chemical quality and fat profile of meat from crossbred goats (native and exotic) reared under feedlot systems. Thirty-two entire male goats were divided in equal number into four racial groups: eight pure Boer breed, eight $3 / 4$ Boer $+1 / 4$ SPRD crossbred, eight $1 / 2$ Boer $+1 / 2$ SPRD crossbred and eight $1 / 2$ Anglo Nubian + $1 / 2$ SPRD crossbred. All goats were reared under feedlot system and slaughtered at the average age and live weight of 223 days and $29 \mathrm{~kg}$, respectively. The chemical composition including moisture, protein, ash, fat, cholesterol, phospholipids and fatty acids was determined. The breed types had no significant effect on moisture, protein, ash, fat, cholesterol and phospholipids contents. However, the percentages of oleic and stearic acids and the MUFA/SFA ratio showed significant differences between the four breed groups, with percentages ranging from 0.72 for $3 / 4$ Boer $+1 / 4$ SPRD crossbred to 0.95 for $1 / 2$ Boer $+1 / 2$ SPRD crossbred. The oleic acid (C18:1) was found in the highest percentage in the fatty acid profile in goat meat, particularly for $1 / 2$ Boer $+1 / 2$ SPRD and $1 / 2$ Anglo $+1 / 2$ SPRD genotypes. The crossing of exotic Boer and Anglo Nubian breeds with the natives SPRD resulted in a goat meat of high quality, even at a ratio of $50 \%$, since the goat meat showed low cholesterol percentage and high protein and unsaturated fatty acids contents.
\end{abstract}

Key Words: Anglo Nubian, Boer, breed, goat meat; meat quality, SPRD

\section{Composição química e perfil lipídico da carne caprina de grupos genéticos terminados em confinamento}

RESUMO - Objetivou-se com este estudo avaliar a composição química e o perfil lipídico da carne de caprinos terminados em confinamento. Utilizaram-se 32 animais machos não-castrados de quatro tipos raciais -8 Boer puros, 8 3/4 Boer + 1/4 SPRD (Sem Padrão Racial Definido), 8 11/2 Boer + 1/2 SPRD e 8 1/2 Anglo Nubiano + 1/2 SPRD - criados em regime de confinamento e abatidos com peso médio de $29,0 \mathrm{~kg}$ e idade média de 223 dias, para avaliação da composição centesimal e dos componentes lipídicos (colesterol, fosfolipídios e ácidos graxos). O genótipo dos animais não teve efeito sobre a composição centesimal e os níveis de colesterol e fosfolipídios da carne, mas influenciaram os percentuais dos ácidos graxos oléico e esteárico e a relação AGMI:AGS, que variou de 0,72 (grupo genético 3/4 Boer + 1/4 SPRD) a 0,95 (grupo 1/2 Boer + 1/2 SPRD). O ácido oléico (C18:1) foi o que mais contribuiu na composição dos ácidos graxos na carne caprina, especialmente nos grupos 1/2 Boer $+1 / 2$ SPRD e $1 / 2$ Anglo + 1/2 SPRD. O cruzamento genético das raças Boer e Anglo Nubiana com nativos SPRD, mesmo na proporção de $50 \%$, resultou em carne de boas qualidades nutricionais, como baixo teor de colesterol, elevado teor protéico e elevado índice de ácidos graxos insaturados.

Palavras-chave: Anglo-Nubiano, Boer, carne caprina, genótipos, qualidade da carne, SPRD

\section{Introduction}

The meat quality is a combination of chemical and sensory attributes and a carcass with better fat/muscle proportions
(Silva \& Silva Sobrinho, 2002). The goat meat has a great merchandising potential, as nowadays consumers tend to raise the goat meat consumption, considering its low fat content when compared to other red meats (Kannan et al., 2001). 
According to Silva Sobrinho \& Gonzaga Neto (2001), the industrial crossing has become a consistent practice in goat production systems, since pure animals have a high price while SPRD (Without Racial Standard Defined) have a lower price and a lower performance. The crossing between native and exotic animals can increase the growth rate and provide better carcass conformation and composition. The efficiency of this process depends on the breed selected, the individuality of animals and their nutritional level.

The excellent features of Boer goats, a meat-type breed, make it preferable when someone wants to select animals for rusticity, fertility, growth potential and carcass quality. Moreover, these animals have the ability to transmit their qualities when used in crossing systems (Madruga et al., 2005). On the other hand, some producers have used Anglo Nubian breed as a paternal race, mainly because it is considered to have a double fitness (meat and milk).

Meat is a food preferred by most consumers; however, it is a food classified with high fat, cholesterol and saturated fatty acids contents and with low unsaturated fatty acids contents (Bragagnolo \& Rodriguez-Amaya, 1992). On the other hand, according to Madruga (2004), goat meat has advantages in comparison to other meats available in the market, such as low fat, high digestibility, high protein, iron and unsaturated fatty acids levels. The Boer breed, originated from South Africa and introduced in Brazil, mostly in the Northeastern region, has been named to ensure the improvement of the quality of native goats (SPRD). The crossing between Boer and native animals has produced weight gain, provided by Boer breed, and maintained the rusticity inherited from native goats (Sousa et al., 1998).

Today, the goat production sector prioritizes the production of high-quality meat. The need to conserve native breeds and to increase the meat production, associated with little information about the ability of these animals to produce high-quality carcasses and meat, encouraged the completion of this study, whose main aim was to evaluate the chemical quality and the fatty acids profile of meat from goats from different genetic groups finished in feedlot system.

\section{Material and Methods}

The study was conducted using 32 non-castrated male goats from four breed types - 8 pure Boer; $83 / 4$ Boer + 1/4 SPRD; $81 \frac{1}{2}$ Boer + $1 / 2$ SPRD; and $81 / 2$ Anglo Nubian + $1 / 2$ SPRD - with initial weight of $18.0 \pm 1.0 \mathrm{~kg}$ and initial age of $135.0 \pm 2.0$ days. During the confinement period in the Pendencia Experimental Station - State of Paraiba
Agricultural Research Agency (EMEPA-PB), the animals were identified, weighed, submitted to health control and housed in individual cages measuring $0.80 \mathrm{~m}$ wide by $1.20 \mathrm{~m}$ in length, with feeders and water suppliers arranged in a hall.

The experiment lasted up to 84 days, including the period of 14 days to adapt to the management and diet. The animals were kept in confinement until they reached the slaughter weight of $29.0 \pm 2.0 \mathrm{~kg}$ and presented, during the confinement period, total weight gain of $10.7 \pm 1.0 \mathrm{~kg}$ and daily weight gain of $147.4 \pm 20.0 \mathrm{~g} / \mathrm{animal} / \mathrm{day}$, which did not differ between genotypes. During this period, all animals were kept under the same experimental diet, as a complete diet, balanced in accordance with the requirements of the AFRC (1993), consisting of 33\% of grass-tifton- 85 hay, $39 \%$ of ground corn , $11.5 \%$ of soybean meal, $7 \%$ of cotton seed meal, $7 \%$ of wheat bran, $1 \%$ of mineral salt and $1 \%$ of limestone (Table 1).

At the end of the confinement period, the animals were submitted to solid fasting and free water for 16 hours; they were slaughtered in accordance with the RIISPOA standards (Brasil, 1997). The carcasses were identified according to animal and genotype, and stored in a cold room, where they were kept for 24 hours at $2{ }^{\circ} \mathrm{C} \pm 0.5^{\circ} \mathrm{C}$.

The Longissimus dorsi muscle was separated from the bone and intramuscular fat for quantitative assessments of chemical composition and lipid profile. They were packed in plastic bags, and finally frozen in commercial freezers at $-18^{\circ} \mathrm{C}$ for a period not exceeding two months, when the tests were performed. All goat meat evaluations were performed in triplicates.

Longissimus dorsi muscle samples were thawed in refrigerator for 24 hours. Then, they were submitted to toilet and ground in blender until obtaining a homogeneous sample. The moisture content was determined maintaining the meat in oven at $105^{\circ} \mathrm{C}$ until constant weight; the ash content was obtained by burning the material in muffle at $550^{\circ} \mathrm{C}$; and the nitrogen content was determined through the Kjeldahl method, using the factor of 6.38 to convert the total nitrogen into protein nitrogen. All constituents were quantified according to the analytical procedures of AOAC (2000). The total lipid levels were measured in accordance with the method of Folch et al. (1957), submitting the sample to extraction with a mixture of chloroform and methanol (2:1 ratio).

The cholesterol determination was carried out in accordance with methodology described by Bragagnolo \& Rodriguez-Amaya (1992), using a UV/visible spectrophotometer (Micronal B395) with wavelength of $490 \mathrm{~nm}$. The phospholipids content was determined in 
Table 1 - Chemical composition of the experimental diet (\% dry matter)

\begin{tabular}{lc}
\hline Ingredient & (\% Dry matter $)$ \\
\hline grass-tifton-85 hay & 33.0 \\
Ground corn & 39.0 \\
Soybean meal & 11.5 \\
Cotton seed meal & 7.0 \\
Wheat bran & 7.0 \\
Mineral salt & 1.0 \\
Limestone & 1.5 \\
\hline Chemical composition (\% Dry matter) & \\
\hline Dry matter & 90.0 \\
Crude protein & 17.1 \\
Ash & 6.9 \\
Organic matter & 93.1 \\
Ether extract & 3.6 \\
Neutral detergent fiber & 30.0 \\
Total carbohydrates & 72.4 \\
Acid detergent fiber & 14.0 \\
Calcium & 2.04 \\
Phosphorus & 0.99 \\
Metabolizable energy (Mcal/kg DM) & 2.8 \\
\hline
\end{tabular}

accordance with methodology described by Pikul et al. (1985), and adapted by Souza (1999), using a UV/visible spectrophotometer (Metertec SP-818) with wavelength of $660 \mathrm{~nm}$ (Rangana, 1991).

The fatty acids methylation was performed using methodology described by Hartman \& Lago (1973). The fatty acids were separated into a gas chromatograph GC model Master, coupled to the FID. The separation occurred in a fused silica capillary column Carbowax 20M (Supelco), polar type, packed with Polyethylene, with dimensions of $60 \mathrm{~m} \times 0.53 \mathrm{~mm}$ id $\times 1 \mu \mathrm{m}$ of film thickness. Methyl esters samples $(2 \mu \mathrm{L})$ were injected into a split/splitless type injector at $250^{\circ} \mathrm{C}$. The chromatograms, with retention times and the percentages of areas of fatty acids were recorded using a Peak simple Software (ARI Instruments - USA). The GC oven used the temperature program, which followed the chromatographic conditions: initial column temperature of $60{ }^{\circ} \mathrm{C}$, kept for 2 minutes, followed by a change in temperature of $5.5^{\circ} \mathrm{C} / \mathrm{min}$ up to $110^{\circ} \mathrm{C}$ in the first ramp, remaining for 6 minutes. A further increase in column temperature was applied using a rate of $3.0^{\circ} \mathrm{C} /$ minute until the final temperature of $165^{\circ} \mathrm{C}$ in the second ramp was reached, keeping this temperature for 10 more minutes. The total time of analysis was 45.4 minutes. Hydrogen gas was used as carrier gas with a flow rate of $5 \mathrm{~mL} /$ minute. The auxiliary gases were nitrogen $(30 \mathrm{~mL} /$ minute $)$, hydrogen (30 mL/minute) and synthetic air $(300 \mathrm{~mL} /$ minute $)$. The fatty acids were identified by comparing the retention times of methyl esters of the samples with authentic standards (Merck, USA). The fatty acids results were expressed as percentage of area (\%).

The data was submitted to analysis of variance (ANOVA) using the F test to compare the mean squares and to determine the significance of the effect of genotype factor in a completely randomized design with four genetic groups and eight repetitions, using the statistical program Statistical Analysis System (SAS), version 6.12 (SAS, 1996). The averages were compared by Tukey test at $5 \%$ probability.

\section{Results and Discussion}

Genotype had no effect $(\mathrm{P}>0.05)$ on the moisture, ash, protein, lipid, cholesterol and phospholipids parameters in Longissimus dorsi muscle from goats. According to the results (Table 2), the meat was characterized as a red "lean", with low fat content, from animals raised in feedlot system and slaughtered still young. Hogg et al. (1992) reported that goat meat contains little fat and higher proportions of protein and minerals, which results in favourable protein/ fat ratio, consistent with the nutritional requirements of current consumer (Raljic et al., 1995), including South African countries (Tshabalala et al., 2003).

In general, the lipid deposition on the goat carcass only occurs when the animal reaches maturity or a body weight of $40 \mathrm{~kg}$ (Madruga et al., 2000), which may explain the similarity between the groups slaughtered with weight lower than $40 \mathrm{~kg}$. The low level of lipids observed in this study may also be related to the sample analyzed, since the Longissimus dorsi muscle was separated from the bone and intermuscular fat.

Fat values higher than those found in this study, with concentrations of $10.45 \mathrm{~g} / 100 \mathrm{~g}$ in Boer genotype, were found by Tshabalala et al. (2003) in a study on the quality of goat meat from South Africa breeds, in which the Longissimus dorsi along with the subcutaneous fat from the carcass of animals was analyzed. Gibb et al. (1993) also reported significant influence of the breed in the humidity, in the crude protein. According to these authors, the fat levels from the carcasses of Saanen goats and Anglo Nubian and Boer crossbred ranged from 10 to $13 \mathrm{~g} / 100 \mathrm{~g}$, as a result of the high variation in the intermuscular fat index from these animals. Similarly, Dhanda et al. (2003) researched the quality of the meat from six goat genotypes in Australia and found that the protein and fat parameters differed between Boer $\times$ Mohair, Boer $\times$ Feral, Boer $\times$ Saanen genotypes slaughtered with a final weight from 30 to $35 \mathrm{~kg}$ and 7 to 8 months of age. 
Table 2 - Chemical composition and lipid of goat meat from four genetic groups finished under feedlot system

\begin{tabular}{lrrrr}
\hline Variable & \multicolumn{4}{c}{ Genetic group } \\
\cline { 2 - 5 } & \multicolumn{1}{c}{ Pure Boer } & \multicolumn{1}{c}{$3 / 4$ Boer $+1 / 4$ SPRD } & $1 / 2$ Boer $+1 / 2$ SPRD & $1 / 2$ Anglo $+1 / 2$ SPRD \\
\hline Humidity $(\mathrm{g} / 100 \mathrm{~g})$ & $72.35 \pm 1.43$ & $72.01 \pm 1.54$ & $72.48 \pm 1.34$ & $72.79 \pm 1.14$ \\
Protein $(\mathrm{g} / 100 \mathrm{~g})$ & $24.53 \pm 0.93$ & $25.22 \pm 1.15$ & $24.40 \pm 0.94$ & $24.18 \pm 1.02$ \\
Lipids $(\mathrm{g} / 100 \mathrm{~g})$ & $3.06 \pm 1.18$ & $2.76 \pm 0.61$ & $2.73 \pm 1.01$ & $2.44 \pm 0.77$ \\
Ash $(\mathrm{g} / 100 \mathrm{~g})$ & $0.98 \pm 0.13$ & $0.98 \pm 0.11$ & $0.97 \pm 0.08$ & $0.99 \pm 0.08$ \\
Cholesterol $(\mathrm{mg} / 100 \mathrm{~g})$ & $64.64 \pm 7.35$ & $61.58 \pm 9.19$ & $56.57 \pm 5.08$ & $56.55 \pm 3.19$ \\
Phospholipids $(\mathrm{mg} / 100 \mathrm{~g})$ & $6.90 \pm 2.97$ & $8.25 \pm 2.76$ & $7.11 \pm 1.63$ & $8.34 \pm 2.33$ \\
\hline
\end{tabular}

The cholesterol concentrations in goat meat from different genetic groups were similar to those described by Pratiwi et al. (2006a) in the thoracic Longissimus muscle of castrated Boer goats slaughtered with different ages and weights: $60.3 \mathrm{mg} / 100 \mathrm{~g}(30 \mathrm{~kg}$, age $<1$ year), $60.4 \mathrm{mg} / 100 \mathrm{~g}(45 \mathrm{~kg}$, age <1 year), $59.3 \mathrm{mg} / 100 \mathrm{~g}(60 \mathrm{~kg}$, 1 year of age), $57.5 \mathrm{mg} / 100 \mathrm{~g}$ ( $75 \mathrm{~kg}, 1.5$ years of age), and $55.2 \mathrm{mg} / 100 \mathrm{~g}(90 \mathrm{~kg}, 2$ years of age $)$. Cholesterol levels in similar age ranges were observed by other authors working with other goat breeds: 50.3 and $56.3 \mathrm{mg} / 100 \mathrm{~g}$ in indigenous breeds of goats slaughtered at 5 to 6 months of age and raised in feedlot system with controlled diet (Kesava Rao et al., 2003); from $57.4 \mathrm{mg} / 100 \mathrm{~g}$ (175 days) to $74.1 \mathrm{mg} / 100 \mathrm{~g}$ (310 days) in Creole $\times$ Anglo Nubian or Saanen or British Alpine genotypes slaughtered at different ages (Madruga et al., 2002).

Lower cholesterol values, from 33.48 to $45.46 \mathrm{mg} / 100 \mathrm{~g}$, were determined by Madruga et al. (2006) when studying the chemical composition of biceps femoris and semimembranosus muscles from goat meat from different genotypes $(1 / 2$ Boer $+1 / 2$ SPRD cross-breed, $1 / 2$ Anglo Nubian $+1 / 2$ SPRD and only SPRD) and systems (feedlot and field). These authors reported that the system has influenced the cholesterol and phospholipids concentrations, and that the genotype $\times$ muscle interaction influenced the levels of lipids and cholesterol, which were higher in animals raised under feedlot system. The animals from this experiment, despite being raised under feedlot system, were slaughtered very young, and consequently presented little fat deposition in the carcass, and probably contributed to the fact that genotype did not influence $(\mathrm{P}>0.05)$ the cholesterol concentrations.

The cholesterol values found in this study can be considered moderate, i.e., $<90 \mathrm{mg} / 100 \mathrm{~g}$ (Pratiwi et al., 2006a), and represent incentive for Boer $\times$ Anglo Nubian crossbred goat producers to invest in increasing the goat production or in the goat meat efficiency associated to nutritional qualities such as the low cholesterol level.

Ten fatty acids were identified in the goat meat chromatograms as follows: six saturated fatty acids (SFA), two monounsaturated fatty acids (MUFA), and two polyunsaturated fatty acids (PUFA). Among the ten fatty acids identified, four fatty acids constituted $95 \%$ of the total areas of the chromatograms: $\mathrm{C} 18: 1, \mathrm{C} 18: 0, \mathrm{C} 16: 0$ and $\mathrm{C} 18: 2$. Oleic acid (C18:1) presented the largest contribution to the fatty acids profile in the meat of goats from the four genotypes (Table 3 ). The percentages of the four major fatty acids were similar to those observed by Pratiwi et al. (2006b), Beserra et al. (2004), Kesava Rao et al. (2003), Tshabalala et al. (2003) and Rhee et al. (2000) in goat meat.

Palmitic and linoleic acids did not differ $(\mathrm{P}>0.05)$ between genotypes; however, lower oleic acid concentration was found in $3 / 4$ Boer $+1 / 4$ SPRD genotype. Consequently, the meat of animals from that group had lower concentrations of total monounsaturated fatty acids in comparison to $1 / 2$ Boer $+1 / 2$ SPRD, pure Boer and $1 / 2$ Anglo Nubian $+1 / 2$ SPRD groups. The genotype influenced $(\mathrm{P}<0.05)$ the percentage of stearic acid (C18:0), contributing more strongly to the saturated fatty acids profile. The oleic acid and stearic acid values found in the meat of $1 / 2$ Anglo $+1 / 2$ SPRD genotype were intermediate $(\mathrm{P}<0.05)$ in relation to the Boer crosbred genotype. According to Rhee et al. (2000), the ingestion of high amounts of long-chain saturated fatty acids increases the serum cholesterol; however, the stearic acid (neutral fatty acid) is rapidly converted into oleic acid by the body after ingestion and does not affect the blood cholesterol (Bressan et al., 2004). These results indicate that the fatty acids profile of the genetic groups studied promotes a desirable nutritional diet, with the presence of adequate amounts of monounsaturated fatty acids and stearic acid (C18:0), that do not affect the blood cholesterol.

Pratiwi et al. (2006b) studied the effect of genotype (Boer and Feral), castration and slaughter weight $(5,30$ and $60 \mathrm{~kg}$ ) in the fatty acids profile in Longissimus thoracic muscle of goat meat and found that the of oleic acid, stearic acid and linoleic acid concentrations did not vary between Feral and Boer breeds; only the palmitic acid was influenced $(\mathrm{P}<0.001)$ by genotype. These authors also found that the concentrations of all fatty acids were significantly affected by the slaughter weight, and that oleic and palmitic acids 
Table 3 - Fatty acids profile (\% area) of goat meat from four genetic groups finished under feedlot system

\begin{tabular}{|c|c|c|c|c|c|}
\hline \multirow[t]{2}{*}{ Variable } & \multirow[b]{2}{*}{ Nomenclature } & \multicolumn{4}{|c|}{ Genetic group } \\
\hline & & Pure Boer & $3 / 4$ Boer + 1/4 SPRD & $1 / 2$ Boer + $1 / 2$ SPRD & $1 / 2$ Anglo $+1 / 2$ SPRD \\
\hline Saturated & & $53.42 \pm 1.15 \mathrm{ab}$ & $55.07 \pm 1.77 \mathrm{a}$ & $49.13 \pm 3.99 b$ & $51.73 \pm 3.24 \mathrm{ab}$ \\
\hline C12:0 & Lauric acid & $0.25 \pm 0.12 \mathrm{ab}$ & $0.27 \pm 0.06 \mathrm{ab}$ & $0.13 \pm 0.03 b$ & $0.32 \pm 0.07 \mathrm{a}$ \\
\hline C14:0 & Myristic acid & $1.78 \pm 0.33 \mathrm{a}$ & $1.78 \pm 0.47 \mathrm{a}$ & $2.27 \pm 0.61 \mathrm{a}$ & $1.83 \pm 0.35 \mathrm{a}$ \\
\hline C16:0 & Palmitic acid & $21.71 \pm 1.07 \mathrm{a}$ & $21.4 \pm 2.13 \mathrm{a}$ & $22.11 \pm 1.73 \mathrm{a}$ & $21.21 \pm 1.33 \mathrm{a}$ \\
\hline Unsaturated & & $46.59 \pm 1.15 \mathrm{ab}$ & $44.93 \pm 1.77 b$ & $50.86 \pm 3.99 a$ & $48.27 \pm 3.24 \mathrm{ab}$ \\
\hline Monounsaturated & & $42.06 \pm 1.25 \mathrm{ab}$ & $39.46 \pm 2.15 b$ & $46.17 \pm 2.92 \mathrm{a}$ & $42.42 \pm 4.33 \mathrm{ab}$ \\
\hline C16:1 & Palmitoleic acid & $1.37 \pm 0.11 \mathrm{a}$ & $1.50 \pm 0.31 \mathrm{a}$ & $1.36 \pm 0.32 \mathrm{a}$ & $1.25 \pm 0.26 \mathrm{a}$ \\
\hline $\mathrm{C} 18: 1 w 9$ & Oleic acid & $40.69 \pm 1.27 \mathrm{a}$ & $37.96 \pm 2.26 \mathrm{~b}$ & $44.81 \pm 3.11 \mathrm{a}$ & $41.18 \pm 4.56 \mathrm{a}$ \\
\hline & Polyunsaturated & $4.52 \pm 0.91 \mathrm{a}$ & $5.46 \pm 0.67 \mathrm{a}$ & $4.70 \pm 1.30 \mathrm{a}$ & $5.84 \pm 1.51 \mathrm{a}$ \\
\hline $\mathrm{C} 18: 2 w 6$ & Linoleic acid & $4.16 \pm 0.85 \mathrm{a}$ & $4.97 \pm 0.89 \mathrm{a}$ & $4.42 \pm 1.46 \mathrm{a}$ & $5.57 \pm 1.60 \mathrm{a}$ \\
\hline$(\mathrm{C} 18: 0+\mathrm{C} 18: 1) / \mathrm{C} 16: 0$ & & $3.22 \pm 0.27 \mathrm{a}$ & $3.25 \pm 0.41 \mathrm{a}$ & $3.13 \pm 0.32 \mathrm{a}$ & $3.26 \pm 0.27 \mathrm{a}$ \\
\hline DFA & & $75.78 \pm 1.64 \mathrm{a}$ & $75.89 \pm 2.59 a$ & $74.87 \pm 2.44 \mathrm{a}$ & $76.00 \pm 2.06 \mathrm{a}$ \\
\hline
\end{tabular}

${ }^{1}$ Averages followed by different letters within a row differ significantly by Tukey test at $5 \%$ probability.

SFA: saturated fatty acids; PUFA: polyunsaturated fatty acids; MUFA: monounsaturated fatty acids.

${ }^{2}$ DFA: desirable fatty acids = MUFA + PUFA + C18:0.

increased, while the stearic acid decreased with increasing weight gain, result not observed in this study because the animals have been slaughtered with similar weight.

Studying the quality of goat meat from South African genotypes compared to sheep breeds (Damara and Dorper) in extensive grazing, Tshabalala et al. (2003) reported that the meat from Boer goats had higher percentage of saturated and unsaturated fatty acids (mono and polyunsaturated) in relation to animals from native breeds (Indigenous) and Damara and Dorper breeds.

From a nutritional point of view, it is important to evaluate the ratios between unsaturated fatty acids and saturated concentrations. In this research, only the monounsaturated: saturated ratio differed $(\mathrm{P}<0.05)$ between the genetic groups, with results ranging from $0.72(3 / 4 \mathrm{Boer}$ $+1 / 4$ SPRD group) to 0.95 ( $1 \frac{1}{2}$ Boer+ $1 / 2$ SPRD group), as a result of the monounsaturated fatty acids concentration, especially by the presence of oleic acid in meat goats.

On the other hand, the values found for the PUFA: SFA ratio were from 0.08 to 0.11 , below those suggested by Wood et al. (2003), who recommended values above 0.4 to prevent illnesses associated with the consumption of fats. Some meats present naturally polyunsaturated: saturated ratio around 0.1 (Williams. 2000), which implies unbalanced consumption of desirable fatty acids (C18:3, C18:2 and C18:1).

According to Banskalieva et al. (2000) and Rhee et al. (2000), the $(\mathrm{C} 18: 0+\mathrm{C} 18: 1) / \mathrm{C} 16: 0$ ratio is the one that best describes the possible beneficial effects of lipids, which values are from 2.1 to 3.6 for goat meat. In this context, the results for meat from Boer and Anglo Nubian $\times$ SPRD crossbred goats (with values from 3.13 to 3.26 ) show that this meat has excellent nutritional qualities. The results in this study, 74 to $76 \%$, are in agreement with authors that reported that the DFA percentage in the fat of goat meat must range from 61 to $80 \%$ and confirm, under the nutritional point of view, the excellence of the Boer, Anglo Nubian and its crossing with SPRD goat meat.

\section{Conclusions}

The genotype did not determine the chemical composition and lipid profile (cholesterol and phospholipids) of meat from Boer and Anglo Nubian $\times$ SPRD crossbred goats; however, the $1 \frac{1}{2}$ Boer $+1 / 2$ SPRD genotype is highlighted by the high percentage of monounsaturated fatty acids in meat, especially oleic acid. In this context, the crossing of Boer and Anglo Nubian breeds with native SPRD, even at a ratio of $50 \%$, result in a goat meat with excellent nutritional qualities, low cholesterol levels and high protein and unsaturated fatty acids contents in relation to other red meats.

\section{Acknowledgements}

We would like to thank CNPq and CAPES for the financial support. We are also grateful to EMEPA/PB, which supplied the animals for the study. 


\section{Literature Cited}

AGRICULTURAL AND FOOD RESEARCH COUNCIL - AFRC. Energy and protein requeriment of ruminant. Wallingford: CAB International, 1993. 159p.

ASSOCIATION OF OFFICIAL ANALYTICAL CHEMISTRY AOAC. Official methods of analysis. 19.ed. Washington, D.C.: AOAC International. 2000. 1219p.

BANSKALIEVA, V.; SAHLU, T.; GOETSCH, A.L. Fatty acid composition of goat muscles and fat depots: a review. Small Ruminant Research, v.37, p.255-268, 2000.

BESERRA, F.J.; MADRUGA, M.S.; LEITE, A.M. et al. Effect of age at slaughter on chemical composition of meat from Moxotó goats and their crosses. Small Ruminant Research, v.55, p. $177-181,2004$.

BRAGagnolo, N.; ROdRIGUEZ-AMAYA, D.B. Teores de colesterol em carne suína e bovina e efeito de cozimento. Ciência e Tecnologia de Alimentos, v.15, n.1, p.11-17, 1992.

BRASIL. MINISTÉRIO DA AGRICULTURA. Regulamento da inspeção industrial e sanitária de produtos de origem animal. Brasília: 1997.

BRESSAN, M.C.; ODA, S.N.I.; CARDOSO, M.G. et al. Efeitos dos métodos de abate e sexo na composição centesimal. perfil de ácidos graxos e colesterol da carne de capivaras. Ciência e Tecnologia de Alimentos, v.24, n.2, p.236-242, 2004.

DHANDA, J.S.; TAYLOR, D.G.; MURRAY, P.J. Carcass composition and fatty acid profiles of adipose tissue of male goats: effects of genotype and liveweight at slaughter. Small Ruminants Research, v. 50, p.67-74, 2003.

FOLCH, J.; FESS, M.; SLOANNE STANLEY, G.H. A simple method for isolation and purification of total lipids from animal tissues. The Journal Biological of Chemistry, v.226, n.1, p.497-509, 1957.

GIBB, M.J.; COOK, J.E.; TREACHER, T.T. Performance of British Saanen Boer $\times$ British Saanen and Anglo Nubian castrated male kids from 8 weeks to slaughter at 28,33 or $38 \mathrm{~kg}$ live weight. Animal Production, v. 57, p.263-271, 1993

HARTMAN, L.; LAGO, B.C. Rapid preparation of fatty methyl esters from lipids. Laboratory Practice, v.22, p.475-477, 1973.

HOGG, B.W.; MERCER, G.J.K.; KIRTON, A.H. et al. Carcass and meat quality attributes of commercial goats in New Zeland. Small Ruminants Research, v.8, p.243-256, 1992.

KANNAN, G.; KOUAUKOU, B.; GELAYE, S. Color changes reflecting myoglobin and lipid oxidation in chevon cuts during refrigerated disply. Small Ruminant Research, v.42, n.1, p.67-75, 2001

KESAVA RAO, V.; KOWALE, B.N.; VERMA, A.K. Effect of feeding water washed neem (Azadirachta indica) seed kernel cake on the quality lipid profile and fatty acid composition of goat meat. Small Ruminant Research, v.47, p.213-219, 2003.

MADRUGA. M.S. Qualidade química. sensorial e aromática da carne caprina: mitos e verdades. In: ENCONTRO NACIONAL PARA O DESENVOLVIMENTO DA ESPÉCIE CAPRINA, 8., 2004, Botucatu. Anais... São Paulo: 2004. p.215-234.

MADRUGA, M.S.; ARRUDA, S.G.B.; BESSERRA, F.J. Efeito da castração sobre parâmetros químicos. físico-químicos e sensoriais da carne caprina de animais mestiços. Ciência e Tecnologia de Alimentos, v.20, n.1, p.23-26, 2000.

MADRUGA, M.S.; NARAIN, N.; ARRUDA, S.G.B. et al. Influência da idade de abate e da castração nas qualidades físico-químicas. sensoriais e aromáticas da carne caprina. Revista Brasileira de Zootecnia, v.31, n.3, p.1562-1570, 2002.

MADRUGA, M.S.; NARAIN, N.; DUARTE, T.F. et al. Características químicas e sensoriais de cortes comerciais de caprinos SRD e mestiços de Boer. Ciência e Tecnologia de Alimentos, v.25, n.4, p.713-719, 2005.

MADRUGA, M.S.; RESOSEMITO, F.S.; NARAIN, N. et al. Effect of raising conditions of goats on physico-chemical and chemical quality of its meat. Ciencia y Tecnologia de los Alimentos. v.5, n.2, p.100-104, 2006.

PIKUL, J.; LESZCZYNSKI, D.E.; KVMMEROW, F.A. Influence of fat content and composition on malomaldehyde concentration in chicken meat and skin. Poultry Science, v.64, p.311-317, 1985

PRATIWI, N.M.W.; MURRAY, P.J.; TAYLOR, D.G. Total cholesterol concentrations of the muscules in castrated Boer goats. Small Ruminant Research, v.64, p.77-81, 2006 a.

PRATIWI, N.M.W.; MURRAY. P.J.; TAYLOR. D.G. et al. Comparison of breed. slaughter weight and castration on fatty acid profiles in the longissimus thoracic muscle from male Boer and Australian feral goats. Small Ruminant Research, v.64, p.94-100, 2006b.

RANGANNA, S. Handbook of analysis and quality control for fruits and vegetables products. New Delhi: Mcgraw-Hill, 1991. 1112p.

RALJIC, J.P.; KRAJINOVIC, M.; MASIC, D.K. et al. Chemical composition of kid meat of the domestic white goat. Acta Veterinaria, v.45, p.303-310, 1995.

RHEE, K.S.; WALDRON, D.F.; ZIPRIN, Y.A. et al. Fatty acid composition of goat diets vs intramuscular fat. Meat Science, v.54, p.313-318, 2000 .

STATISTICAL ANALYSIS SYSTEM - SAS. User's guide to statistics. Versão 6.12. Cary: North Caroline State University. 1996. 956p.

SILVA SOBRINHO, A.G.; GONZAGA NETO, S. Produção de carne caprina e cortes da carcaça. Jaboticabal: Faculdade de Ciências Agrárias e Veterinárias, 2001. 17p.

SILVA SOBRINHO, A.G.; SILVA, A.M.A. Produção de carne caprina e cortes da carcaça. Revista Nacional da Carne, v.24, n.285. p.32-44, 2002.

SOUSA, W.H.; LEITE, R.M.H.; LEITE, P.R.M. Raça Boer - caprinos tipo carne. João Pessoa: EMEPA, 1998. 31p. (Documentos, 31).

SOUZA, J.G. Efeito da castração e da idade de abate nos componentes lipídicos em carne de caprinos mestiços do brejo Paraibano. 1999. 68f. Dissertação (Mestrado em Ciência e Tecnologia de Alimentos) - Universidade Federal da Paraíba, João Pessoa, 1999.

TSHABALALA, P.A.; STRYDOM, P.E.; WEBB, H.L. et al. Meat quality of designated South African indigenous goat and sheep breeds. Meat Science, v.65, p.563-570, 2003.

WILLIAMS, C.M. Dietary fatty acids and human health. Annales Zootechnie, v.49, p.165-180, 2000.

WOOD, J.D.; RICHARDSON, R.I.; NUTE, G.R. et al. Effects of fatty acids on meat quality: a review. Meat Science, v.66, p.21-32, 2003 